\title{
Genomics and genetic breeding in aquatic animals: progress and prospects
}

\author{
Wenteng XU ${ }^{1,2}$, Songlin CHEN $(\bowtie)^{1,2}$ \\ 1 Key Lab for Sustainable Development of Marine Fisheries, Ministry of Agriculture, Yellow Sea Fisheries Research Institute, \\ Chinese Academy of Fishery Sciences, Qingdao 266071, China \\ 2 Laboratory for Marine Fisheries Science and Food Production Processes, Qingdao National Laboratory \\ for Marine Science and Technology, Qingdao 266237, China
}

\begin{abstract}
Genomics focuses on dissection of genome structure and function to provide a molecular basis for understanding the genetic background. In a pivotal step, the expense of whole genome sequencing has been largely eliminated by the rapid updating of sequencing technology, leading to increasing numbers of decoded genomes of aquatic organisms, driving the aquaculture industry into the genomic era. Multiple aquatic areas have been influenced by these findings, such as accelerated generation shift in the seed industry and the process of breeding improved lines. In this article, we have summarized the latest domestic and international progress of aquatic animals in nine aspects, including WGS and fine mapping, construction of high density genetic/physical maps, traitrelated marker/genes screening, as well as sex control, genome editing, and other molecular breeding technologies. Finally, the existing problems in this field have been discussed and five future counter measures have been proposed accordingly.
\end{abstract}

Keywords aquaculture, genomics, genetic breeding, progress

\section{Introduction}

Genomics is a subject that concentrates on studying genome structure and function. As the first step in genomic structural analysis, whole genome sequencing (WGS) plays a pivotal role in genetic resource exploitation and functional gene discovery. Through WGS the genomic sequences and important functional genes are obtained, which can in turn reveal the evolution of the species, as well as facilitate understanding of the molecular

Received December 30, 2016; accepted March 2, 2017

Correspondence: chens1@ysfri.ac.cn mechanism of growth, development, reproduction, sex differentiation and environmental adaptation. In recent years, the rapid development of sequencing technology has resulted in a sharp decline of sequencing cost, so WGS has been accomplished in a number of aquatic organisms. This has led to the rapid accumulation of massive genomic resources and the identification of many markers/genes related to important traits. These findings have greatly promoted the study of multiple aquatic areas, e.g., identification of aquatic germplasm, genetic dissection of important traits, molecular sex control, genetic improvement, genome editing and whole genome selection, and thus driven the aquaculture industry into the genomic era. On the one hand, the development of genomic technologies has facilitated the generation shift in the seed industry and breeding process of improved lines. On the other hand, genomic resources and technologies have also provided huge application potential and improved prospects for aquatic breeding, germplasm conservation, disease control and prevention. This article summarizes the latest progress in aquatic animals, including fine mapping of genomes, screening of markers and genes related to important traits, construction of high-density genetic/physical maps, marker assisted sex control, genome editing, and whole genome selection. Finally, the existing problems are discussed and future development in aquatic genome and genetic breeding technology proposed.

\section{Recent progress in genome research in aquatic animals}

\subsection{Whole genome sequencing and fine mapping}

WGS in aquatic animals can be dated from the beginning of this century. In 2002, Singaporean scientists deciphered the genome of fugu rubripes, the first animal in aquaculture 
to be sequenced ${ }^{[1]}$. Subsequently, domestic and foreign scientists have completed the genomic sequencing and fine mapping of the Atlantic cod, Atlantic salmon, carp, grass carp, half-smooth tongue sole, large yellow croaker, oysters, rainbow trout, tilapia, tuna and other important animals inaquaculture.Among them, the genome of Atlantic cod was decoded by University of Oslo in $2011^{[2]}$, three stickleback by Stanford University and the Broad Institute in $2012^{[3]}$, zebrafish by the Sanger Institute in $2013^{[4]}$, rainbow trout (first trout species sequenced) by French scientists in $2014^{[5]}$ and Atlantic salmon by the Norwegian University of Life Sciences in $2016^{[6]}$.

In recent years, Chinese scientists have also made great progress, for example, the sequencing of oyster genome by Zhang's group from the Institute of Oceanology, Chinese Academy of Sciences (IOCAS) ${ }^{[7]}$ and half-smooth tongue sole, the world's first Pleuronectiformes sequenced and the first fish sequenced in China, was completed by Chen's team from the Yellow Sea Fisheries Research Institute, Chinese Academy of Fishery Sciences (YSFRI, CAFS) ${ }^{[8]}$. Soon afterwards, genomes of other fish were published, including carp (Sun's laboratory from Heilongjiang Fisheries Research Institute, CAFS) ${ }^{[9]}$, large yellow croaker genome (Wu's laboratory from Zhejiang Ocean University) ${ }^{[10]}$ and grass carp genome (Wang's laboratory, Institute of Hydrobiology, Chinese Academy of Sciences) ${ }^{[11]}$. Sequenced aquatic animal genomes and their features are listed in Table 1.

\subsection{High-density genetic linkage maps}

High-density genetic linkage mapping has served as an important tool for genome assembly, important economic trait-related QTL mapping and gene screening. The sequencing of aquatic genomes can identify a large number of polymorphic SSR and SNP markers, which provide sufficient resources for construction of high density genetic linkage maps. Over the past five years, high density genetic linkage maps have been constructed for over 20 important aquatic animals, including Japanese flounder ${ }^{[29,30]}$, half-smooth tongue sole ${ }^{[8,31]}$, common $\operatorname{carp}^{[32]}$, channel cattish ${ }^{[33]}$, rainbow trout ${ }^{[34]}$, turbot ${ }^{[35,36]}$, Nile tilapia ${ }^{[37]}$, Atlantic salmon ${ }^{[38]}$, large yellow croa$\operatorname{ker}^{[39,40]}$, silver carp ${ }^{[41]}$ bighead carp ${ }^{[42]}$, orange-spotted grouper $^{[43]}$, European seabass ${ }^{[44]}$, red drum ${ }^{[45]}$, bay scallop $^{[46]}$, Zhikong scallop ${ }^{[47]}$ and Pacific white shrimp ${ }^{[48]}$. These successes have laid a solid foundation for fine mapping of disease resistance-related QTLs or gene cloning. For example, with an SNP genetic linkage map and genome-wide association analysis, Geng et al. located a $620 \mathrm{~kb}$ QTL region on the catfish chromosome 7. This QTL contained five immune related genes that might play a role in columnaris disease resistance ${ }^{[49]}$. The reported high-density genetic linkage maps of aquatic animals are summarized in Table 2.

\subsection{Construction of physical maps}

The construction of physical maps for aquatic animals was initiated in 2004 and has so far been successful for over 10 species, including the Asian sea bass ${ }^{[50]}$, Atlantic salmon $^{[51]}$, channel catfish ${ }^{[52,53]}$, common carp ${ }^{[54]}$, rainbow trout ${ }^{[55]}$, half-smooth tongue sole ${ }^{[56]}$, Medaka ${ }^{[57]}$, threespine sticklebacks ${ }^{[58]}$, tilapia ${ }^{[59]}$, Zhikong scallop ${ }^{[60]}$ and large yellow croaker (the first optical physical map in a non-model animal) ${ }^{[61]}$. The reported physical maps of aquatic animals are summarized in Table 3.

\subsection{Cloning and analysis of genes related to important traits in aquatic animals}

\subsubsection{Sex determination genes}

For many years, scientists have focused on identifying the key genes in processes such as sex determination and differentiation, and this is also the case in aquatic animals. With the recent advance of high-throughput sequencing technology, remarkable progress has been achieved and many candidate genes in sex determination/differentiation have been identified, such as DMY, Amhy, Gsdf, Amhr2, SdY, Sox3, Sox9, SoxE, dmrt1 and Amh ${ }^{[62-66]}$. Except for a few reports in shrimp, shellfish and other species, most of these genes have been identified from fish, including $D M Y$ in medaka, Amhy in Odontesthes hatcheri, Gsdf in Oryzias luzonensiss, Sox3 in Oryzias dancena, SdY in Oncorhynchus mykiss, Amhr2 in Takifugu rubripes ${ }^{[65-68]}$. A further study found that Amhy, Gsdf and Amhr2 were nontranscription factors, and all three were involved in the TGF- $\beta$ signaling pathway ${ }^{[63]}$, which was suggested to be an important pathway in the sex determination process and also implied the conservation of sex determining mechanism among different fish species.

Chinese scientists have also made great progress in screening sex determination genes. Based on whole genome sequencing, Shao et al. has uncovered the epigenetic mechanism of sex reversal in half-smooth tongue sole ${ }^{[69]}$. They found that the $\mathrm{Z}$ chromosome-linked gene $d m r t 1$ was testis specific and indispensable for testis development. Dmrt1 was further confirmed to be the male determining gene through TALEN technology ${ }^{[8,70]}$. Researchers from Southwest University have knocked out the dmrt1 gene in tilapia with TALENs technology. The knockout mutant showed an obvious phenotype in the testis, including the deformation of the seminiferous duct and the degeneration of germ cells ${ }^{[71]}$.

\subsubsection{Immune related genes}

Disease is among the top factors that lead to huge economic loss in aquaculture, thus it is becoming a 
Table 1 Reported genomes of aquatic animals by de novo sequencing

\begin{tabular}{|c|c|c|c|c|c|}
\hline Common name & Scientific name & Genome size & ContigN50 & ScaffoldN50 & Reference \\
\hline Fugu rubripes & Takifugu rubripes & $380 \mathrm{Mb}$ & $\mathrm{n} / \mathrm{a}$ & $\mathrm{n} / \mathrm{a}$ & {$[1]$} \\
\hline Puffer fish & Tetraodon nigroviridis & $340 \mathrm{Mb}$ & $16 \mathrm{~kb}$ & $984 \mathrm{~kb}$ & [12] \\
\hline Medaka & Oryzias latipes & $700 \mathrm{Mb}$ & $9.8 \mathrm{~kb}$ & $1.41 \mathrm{Mb}$ & [13] \\
\hline Atlantic cod & Gadus morhua & $830 \mathrm{Mb}$ & $2.8 \mathrm{~kb}$ & $688 \mathrm{~kb}$ & [2] \\
\hline Channel catfish & Ictalurus punctatus & $783 \mathrm{Mb}$ & $77.2 \mathrm{~kb}$ & $7.7 \mathrm{Mb}$ & {$[14]$} \\
\hline Pacific oyster & Crassostrea gigas & $559 \mathrm{Mb}$ & $19.4 \mathrm{~kb}$ & $401 \mathrm{~kb}$ & [7] \\
\hline Pearl oyster & Pinctada fucata & $1.15 \mathrm{~Gb}$ & $1.6 \mathrm{~kb}$ & $14.5 \mathrm{~kb}$ & [15] \\
\hline Threespine stickleback & Gasterosteus aculeatus & $463 \mathrm{Mb}$ & $83.2 \mathrm{~kb}$ & $10.8 \mathrm{Mb}$ & [3] \\
\hline Lamprey & Petromyzon marinus & $816 \mathrm{Mb}$ & $174 \mathrm{~kb}$ & $\mathrm{n} / \mathrm{a}$ & [16] \\
\hline Zebrafish & Danio rerio & $1.4 \mathrm{~Gb}$ & $\mathrm{n} / \mathrm{a}$ & $1.55 \mathrm{Mb}$ & [4] \\
\hline African coelacanth & Latimeria chalumnae & $2.86 \mathrm{~Gb}$ & $12.7 \mathrm{~kb}$ & $924 \mathrm{~kb}$ & [17] \\
\hline Pacific bluefin tuna & Thunnus orientalis & $800 \mathrm{Mb}$ & $7.5 \mathrm{~kb}$ & $136 \mathrm{~kb}$ & [18] \\
\hline Platyfish & Xiphophorus maculatus & $750-950 \mathrm{Mb}$ & $22 \mathrm{~kb}$ & $1.1 \mathrm{Mb}$ & [19] \\
\hline Soft-shell turtle & Pelodiscus sinensis & $2.21 \mathrm{~Gb}$ & $21.9 \mathrm{~kb}$ & $3.3 \mathrm{Mb}$ & {$[20]$} \\
\hline Elephant shark & Callorhinchus milii & $937 \mathrm{Mb}$ & $46.6 \mathrm{~kb}$ & $4.5 \mathrm{Mb}$ & [21] \\
\hline Antarctic bullhead notothen & Notothenia coriiceps & $637 \mathrm{Mb}$ & $11.6 \mathrm{~kb}$ & $219 \mathrm{~kb}$ & [22] \\
\hline Half-smooth tongue sole & Cynoglossus semilaevis & $477 \mathrm{Mb}$ & $26.5 \mathrm{~kb}$ & $867 \mathrm{~kb}$ & [8] \\
\hline \multirow{4}{*}{$\begin{array}{l}\text { Four representative } \\
\text { mudskippers }\end{array}$} & Scartelaos histophorus & $806 \mathrm{Mb}$ & $8.4 \mathrm{~kb}$ & $14.3 \mathrm{~kb}$ & \multirow{4}{*}{ [23] } \\
\hline & Boleophthalmus pectinirostris & $983 \mathrm{Mb}$ & $20.2 \mathrm{~kb}$ & $2.31 \mathrm{Mb}$ & \\
\hline & Periophthalmodon schlosseri & $780 \mathrm{Mb}$ & $16.8 \mathrm{~kb}$ & $39.1 \mathrm{~kb}$ & \\
\hline & Periophthalmus magnuspinnatus & $739 \mathrm{Mb}$ & $27.6 \mathrm{~kb}$ & $288.5 \mathrm{~kb}$ & \\
\hline Common carp & Cyprinus carpio & $1.53 \mathrm{~Gb}$ & $68.4 \mathrm{~kb}$ & $1 \mathrm{Mb}$ & [9] \\
\hline \multirow[t]{2}{*}{ Large yellow croaker } & Larimichthys crocea & $644 \mathrm{Mb}$ & $25.7 \mathrm{~kb}$ & $498.7 \mathrm{~kb}$ & {$[10]$} \\
\hline & Larimichthys crocea & $679 \mathrm{Mb}$ & $63.11 \mathrm{~kb}$ & $1.03 \mathrm{Mb}$ & [24] \\
\hline Tawny puffer & Takifugu flavidus & $390 \mathrm{Mb}$ & $2.8 \mathrm{~kb}$ & $305.7 \mathrm{~kb}$ & {$[25]$} \\
\hline \multirow{2}{*}{ Grass carp } & Ctenopharyngodon idellus (female) & $900 \mathrm{Mb}$ & $40.8 \mathrm{~kb}$ & $6.46 \mathrm{Mb}$ & \multirow{2}{*}{ [11] } \\
\hline & Ctenopharyngodon idellus (male) & $1.07 \mathrm{~Gb}$ & $18.25 \mathrm{~kb}$ & $2.28 \mathrm{Mb}$ & \\
\hline Killfish & Nothobranchius furzeri & $1.24 \mathrm{~Gb}$ & $\mathrm{n} / \mathrm{a}$ & $494 \mathrm{~kb}$ & {$[26]$} \\
\hline Silver pomfret & Pampus argenteus & $550 \mathrm{Mb}$ & 499 bp & $1.58 \mathrm{~kb}$ & [27] \\
\hline Spotted gar & Lepisosteus oculatus & $945 \mathrm{Mb}$ & $68.3 \mathrm{~kb}$ & $6.9 \mathrm{Mb}$ & [28] \\
\hline Atlantic salmon & Salmo salar & $2.97 \mathrm{~Gb}$ & $57.6 \mathrm{~kb}$ & $2.97 \mathrm{Mb}$ & [6] \\
\hline
\end{tabular}

Note: n/a, not available.

key topic foraquaculture. The studies mainly include identification of immune related genes, elucidation of disease resistance mechanisms and improvement of disease resistance in aquatic animals. Recent progress in this area is summarized below.

Chinese scientists have made great contribution in this field. Dozens of immune related genes have been identified and characterized from fish (common carp, grass carp, grouper, half-smooth tongue sole, Japanese flounder, large yellow croaker, sea bass, silver carp and turbot), crustacean (shrimp and crab) and other aquatic animals. Among them, STAT2, GRIM-19, hepcidin, ferroportin1, transferrin receptor in turbot, akirin 1, HEPN and $C 1 Q$ in Japanese flounder, and ghC1q and interferon regulatory factor 1 in half-smooth tongue sole have been identified and their structures, expression patterns and immune functions further analyzed ${ }^{[72-74]}$. Beside genes, a series of microRNAs associated with disease resistance have been identified in half-smooth tongue sole ${ }^{[75]}$. Chinese scientists have also made great progress in this field. Sun's team from IOCAS has cloned and analyzed the turbot chemokine and half-smooth tongue sole nuclear transcription factor and $\mathrm{Hu}$ et al. from the Ocean University of China have cloned and carried out functional analysis 
Table 2 Reported high-density genetic linkage maps of aquatic animals

\begin{tabular}{|c|c|c|c|c|c|c|}
\hline Common name & Maker type & No. of markers & Map size/cM & Linkage groups (No.) & Average interval/cM & Reference \\
\hline Half-smooth tongue sole & SSR & 1024 & 1667.3 & 21 & 1.7 & [31] \\
\hline Half-smooth tongue sole & SNP & 12142 & $\mathrm{n} / \mathrm{a}$ & 21 & 0.326 & [8] \\
\hline Japanese flounder & SSR & 841 & 1733.8 & 24 & 2.22 & [29] \\
\hline Japanese flounder & SNP & 13362 & 3497.29 & 24 & 0.47 & [30] \\
\hline Common carp & SSR & 732 & 3278 & 50 & 4.48 & [32] \\
\hline Channel catfish & SNP & 54342 & 3505.4 & 29 & 0.22 & [33] \\
\hline Rainbow trout & $\begin{array}{l}\text { SSR } \\
\text { SNP }\end{array}$ & 2226 & 2900 & 29 & 1.3 & [34] \\
\hline Large yellow croaker & SSR & 289 & 1430.8 & 24 & 5.4 & [40] \\
\hline Large yellow croaker & SNP & 10150 & 5451.3 & 24 & 0.54 & [39] \\
\hline Silver carp & SSR & 703 & 1561.1 & 24 & 2.2 & [41] \\
\hline Bighead carp & SSR & 659 & 1917.3 & 24 & 2.9 & [42] \\
\hline orange-spotted grouper & SNP & 4608 & 1581.7 & 24 & 0.34 & [43] \\
\hline Turbot & SSR & 438 & 1402.7 & 24 & 3.7 & [35] \\
\hline Turbot & SNP & 6647 & 2262.09 & 22 & 0.395 & [36] \\
\hline European sea bass & SNP & 6706 & 4816 & 24 & 0.72 & [44] \\
\hline Red drum & SSR & 486 & 1815.3 & 24 & 3.96 & [45] \\
\hline Bay scallop & SSR & 161 & 849 & 16 & 5.9 & [46] \\
\hline Zhikong scallop & $\mathrm{n} / \mathrm{a}$ & 3806 & 1543 & 19 & 0.41 & [47] \\
\hline Pacific white shrimp & SNP & 6146 & 4271.43 & 44 & 0.7 & [48] \\
\hline
\end{tabular}

Note: $\mathrm{n} / \mathrm{a}$, not available.

Table 3 Physical maps of aquatic animals

\begin{tabular}{|c|c|c|c|c|c|c|c|}
\hline Common name & Scientific name & $\begin{array}{l}\text { No. of } \\
\text { BACs }\end{array}$ & $\begin{array}{c}\text { No. of BACs for } \\
\text { assembly }\end{array}$ & $\begin{array}{l}\text { No. of } \\
\text { contigs }\end{array}$ & $\begin{array}{l}\text { No. of clones } \\
\text { per contig }\end{array}$ & $\begin{array}{l}\text { Average size of } \\
\text { contig } / \mathrm{kb}\end{array}$ & Reference \\
\hline Medaka & Oryzias latipes & 64512 & 41882 & $\mathrm{n} / \mathrm{a}$ & $\mathrm{n} / \mathrm{a}$ & $\mathrm{n} / \mathrm{a}$ & [56] \\
\hline $\begin{array}{l}\text { Threespine } \\
\text { stickleback }\end{array}$ & Gasterosteus aculeatus & 102178 & 71211 & 8397 & 8.4 & $\mathrm{n} / \mathrm{a}$ & {$[58]$} \\
\hline Tilapia & Oreochromis niloticus & 40704 & 35245 & 3621 & 9 & 389.9 & [59] \\
\hline Atlantic salmon & Salmo salar & 200640 & 185938 & 4354 & 34 & 592 & [51] \\
\hline Channel catfish & Ictalurus punctatus & 40416 & 34580 & 3307 & 9.25 & 292 & [52] \\
\hline Rainbow trout & Oncorhynchus mykiss & 192096 & 154439 & 4173 & 34.75 & 482 & [57] \\
\hline Asian seabass & Lates calcarifer & 38208 & 35265 & 2865 & 11 & 232 & [50] \\
\hline Common carp & Cyprinus carpio & 89088 & 72158 & 3696 & 18.26 & 476 & [54] \\
\hline $\begin{array}{l}\text { Half-smooth tongue } \\
\text { sole }\end{array}$ & Cynoglossus semilaevis & 33575 & 30294 & 1485 & 20 & 537 & [55] \\
\hline Zhikong scallop & Chlamys farreri & 63641 & 37046 & 3696 & 10 & 490 & {$[60]$} \\
\hline
\end{tabular}

Note: n/a, not available.

of interferon regulatory factors 5,8 , and 9 in Japanese flounder ${ }^{[76]}$. Teams from Nanjing Normal University have cloned Toll-like receptors, antimicrobial peptides, immunoglobulin, lectin and other important immune related genes ${ }^{[7]}$. A research group at the Institute of Hydrobiology have systematically studied interferon
$(I F N)$ genes and their regulatory mechanism in fish and produced a draft IFN regulatory network illustrating the role of key genes in the antiviral pathway ${ }^{[78,79]}$. Wang's group from Jimei University has systematically identified and characterized components of the TLR and $\mathrm{Ran} / \mathrm{Rab} / \mathrm{Rac}$ small $\mathrm{G}$ protein signaling pathways in 
large yellow croaker ${ }^{[80-83]}$. Chen's group from the Third Institute of Oceanography, State Oceanic Administration has also characterized a series of immune-related genes in this fish, such as toll-like receptor, chemokine $^{[84,85]}$. These studies have laid an important foundation for revealing the mechanism of immune regulation and exploring the molecular approaches to improve disease resistance in aquatic animals.

\subsubsection{Growth- and reproduction-related genes}

Growth is one of the most important economic traits in aquatic organisms, and a number of genes have been found to have important roles in growth and development, such as growth hormone $(G H)$, GH releasing hormone $(G H R H)$, $\mathrm{GH}$ binding protein, $\mathrm{GH}$ receptor, insulin-like growth factor, and leptin. In recent years, several GH-inhibiting hormones and their receptors have been cloned from grouper (Epinephelus coioides), e.g., two feeding-related receptor genes $n p y 8 b r$ and $n p y 2 r$, cysteamine and neuropeptide Y. Cysteamine was found to promote pituitary $G H$ expression while neuropeptide Y plays a role in GH secretion ${ }^{[86]}$. In half-smooth tongue sole, the growth-related genes $G H, G H R H$, and pituitary adenylate cyclase activating polypeptide were also cloned and studied. It was found that the expression level of $G H$ in pituitary was much higher in females than in male, and this may be an important reason why female tongue sole grows faster than the males ${ }^{[87-90]}$.

Aquatic animal reproduction is regulated by the neuroendocrine axis, and several hormones including gonadotropin-releasing hormone, gonadotropin-releasing hormone, follicle stimulating hormone, and luteinizing hormone, are involved in reproductive regulation. In recent years, kisspeptin, which can tune gonadal differentiation and other signaling pathways, is considered to be a key regulator in vertebrate reproduction. Cloning and characterizationof tilapia kiss gene revealed that it was indirectly regulated by thyroid hormone $\mathrm{T} 3$. The grouper melatonin receptor gene $M T 1$ was cloned and its influence on kiss 2 expression was reported. In contrast to kiss genes, gonadotropin inhibitory hormone is generally recognized as a negative regulator in the reproductive axis ${ }^{[91]}$. In addition to these findings, genes related to other reproductive processes have also investigated and recently, researchers have cloned and characterized teskl and neurl3 in half-smooth tongue sole, suggesting their roles in spermatogenesis ${ }^{[92,93]}$.

\subsection{Screening and application of molecular markers related} to important traits in aquatic animals

\subsubsection{Sex specific markers}

Many aquatic animals exhibit significant sexual dimorphism in growth, a particularly frequent phenomenon in fish. For example, female flatfish grows 2-4 times faster than the males, while in yellow catfish and tilapia, the growth of males was $30 \%-100 \%$ faster than that of females. Thus, it is very important to screen sex-specific markers and develop sex control technology, in order to enhance aquaculture productivity. However, due to the low degree of sex chromosome differentiation, it is difficult to distinguish sex chromosomes at the morphological level, which hinders the direct selection of specific molecular markers from sex chromosome. Although many studies have focused on screening of fish sex-specific markers, so far male specific DNA fragments or AFLP have only been reported for rainbow trout, Atlantic salmon, African catfish, yellow catfish, rock bream, and tilapia $^{[94]}$. In comparison, the number of female specific markers (AFLP and SSR) identified in fish were much lower, for example in half-smooth tongue sole and spotted halibut. Through the comparison of female and male tongue sole genomes, female-specific SSR markers have been identified and a technique for genetic sex identification has been established $^{[94]}$.

\subsubsection{Disease resistance-related markers}

In the breeding process, disease is a leading factor that seriously affects aquatic animals and limits sustainable development of aquaculture. Current treatments have several disadvantages including antibiotic residues, environmental pollution, and health risk to consumers. Screening disease resistance-related markers and breeding disease resistant lines would be a promising solution to overcome these problems in aquatic animals and has become a worldwide hot spot. Recently, great progress has been achieved in this field. Norwegian scientists initiated the study of resistance-related $M H C$ genes in Atlantic salmon $^{[95]}$. Rodriguez-Ramilo et al. found an anti-ciliate related SSR marker, Sma-USC256, in turbot ${ }^{[96]}$ and Duttaet et al. found a RAPD-SCAR marker related to white spot disease (WSD) resistance in Penaeus monodon, and subsequently identified another 71bp SSR marker associated with $\mathrm{WSD}^{[97,98]}$. In rainbow trout, Campbell et al. isolated SNP markers related to bacterial cold water disease and infectious hematopoietic necrosis virus ${ }^{[99]}$. Also, Japanese scientists have screened Lymphocystis disease resistance SSR markers, which have been used for vaccine development.

Chinese scientists also carried on the screening of MHC genes and SSR markers related to Vibrio anguillarum in Japanese flounder, common carp and half-smooth tongue sole. For example, Wang et al. identified two SSR markers associated with $V$. anguillarum disease in Japanese flounder using the established families ${ }^{[100]}$ and Nie et al. found three EST-SSR markers (MM959, MM4765, MM8364) associated with $V$. anguillarum in Meretrix meretrix $^{[101]}$. 


\section{Recent progress in aquatic animals breeding research}

\subsection{Sex control and monosexual breeding in aquatic} animals

Many fish exhibit obvious sexual dimorphism in growth and reproduction. For example, in yellow catfish, tilapia and snakehead, male individuals grow 30\%-200\% faster than the females, while in many marine fish, females can grow $30 \%-300 \%$ faster than males ${ }^{[102]}$. Half-smooth tongue sole is the best example of sexual difference in growth, with females being nearly 2-4 times larger than males ${ }^{[103]}$. Hence, the study of sex control has important potential applications in fish culture and breeding. In this study, sex specific molecular marker selection is the most important technique for the final realization of sex control. Over the past five years, Songlin Chen from YSFRI directed and accomplished the Special Fund for Agroscientific Research in the Public Interest (Project: Research on fish sex control and monosexual fry breeding techniques). Artificial gynogenesis and marker-assisted sex control technique were investigated in this project for several important fish in China, including half-smooth tongue sole, Japanese flounder, tilapia, large yellow croaker, grouper, sturgeon, and carp. In yellow catfish, with the identification male-specific markers, an all-male breeding technique has been developed and all-male fry have been obtained. Using female-specific SRR markers in half-smooth tongue sole, the explanation and mechanism accounting for low female ratio (20\%) in cultured populations was elucidated. Based on these findings, high female breeding was established and applied. The book "Fish Sex Control and Cell Engineering Breeding" was a landmark publication resulting from this project, being, the first academic monograph in this field ${ }^{[102]}$.

The main types of sex determination in fish involve genetic or genetic-environmental mechanisms. Temperature can affect sex differentiation and gonadal development. In 59 fish species, sex differentiation was found to be regulated by temperature, most of which showed sex reversal (genetic female to phenotypic male) at high temperature, such as Japanese flounder and half-smooth tongue sole. In 2011, Navarro-Martín et al. found that DNA methylation is important in temperature dependent regulation of sex differentiation in European seabass ${ }^{[104]}$. More recently, through whole genome methylation analysis in half-smooth tongue sole, Chen and his colleagues have found that in sex-reversed fish (pseudomale), $38 \%$ of the $\mathrm{W}$ chromosome genes are methylated. Moreover, they found the methylation pattern of the sex determination gene dmrtl can be inherited by the next generation, so offspring of pseudomalesare more prone to becoming pseudomales ${ }^{[8,69]}$. This explains the increasing proportion of phenotypic males in cultured populations, which has laid the foundation for studying sex control in half-smooth tongue sole.

\subsection{Molecular breeding technology in aquatic animals}

Developments in molecular biology technology have driven the breeding of aquatic animals into a molecular breeding era. In the early stages, molecular breeding relied mainly on transgenic techniques and molecular marker assisted breeding. Over the past 10 years, the study of transgenic fish has mainly focused on edible and ecological safety. Auburn University succeeded in regulation of primordial germ cell migration through transgenic techniques. In this system, exogenous drugs can be used as gene expression switches to control the fish gonadal development by regulating exogenous genes, dead end and nanos ${ }^{[105]}$. In November 2015, the US Food and Drug Administration approved the marketing of transgenic salmon with the $G H$ gene. This is the first edible transgenic aquatic animal in the world and has significantly promoted the industrialization process of transgenic aquatic animals.

In recent years, only a few Chinese groups have focused on transgenic fish due to the concern about the ecological safety. Therefore, the current work is mainly involved in transgenic fish sterility and ecological safety assessment. The successful production of sterile Yellow River carp expressing the grass carp $G H$ gene laid a foundation to promote the breeding of transgenic fish. As an alternative approach, the genomic sequencing and fine mapping of oysters, half-smooth tongue sole, common carp, large yellow croaker and grass carp, have provided abundant genetic resources for genome-wide selective breeding $^{[7-11]}$. This technique employs genome-wide SNP markers to estimate the genomic breeding value, aiding the selection of individuals with high genetic effect and breeding value. Such genome-wide selective breeding is accurate, rapid and efficient, and is now considered the most promising animal breeding technology in the world and attracts much attention from international research teams ${ }^{[106-108]}$. During the 12th Five-Year Plan, China has launched genome-wide selective breeding programs for large yellow croaker, half-smooth tongue sole, shrimp, oysters and scallop, and these programs have made considerable progress. The preliminary technique platform was established for scallop, oysters, half-smooth tongue sole, large yellow croaker and Japanese flounder. With the application in practical breeding, a US team has developed a $250 \mathrm{~K} \mathrm{SNP}$ chip for channel catfish ${ }^{[109]}$ and a Chinese team has explored using a high throughput SNP chip for common carp ${ }^{[110]}$.

\subsection{Breeding of fine lines}

China has attached great importance to genetic improvement and cultivation of fine lines of aquatic animals. Over 
the past 30 years, with the support of the National Basic Research Program of China, National High-tech R\&D Program of China, and National Key Technology R\&D Program, research for fine line breeding has been extensively conducted for aquatic animals, including fish, shrimp, shellfish, crabs, sea cucumbers and sea urchins. Various technologies, such as crossbreeding, population or family selection, artificial gynogenesis, molecular marker assisted selection, and BLUP technology, have been used in this process, which aimed to screen the individuals with desired traits, e.g., fast growth, disease resistance and stress resistance. So far, more than 100 new lines of aquatic animals have been developed, including common carp, bream, tilapia, silver crucian carp, Japanese flounder, turbot, large yellow croaker, Chinese shrimp, abalone, oysters, pearl shell and clams. These successes have not only facilitated the breeding process for fine lines of aquatic animals, but have also promoted the rapid development of the aquaculture industry.

\subsection{Gene editing technology}

Gene editing is a newly developed gene targeting technology, which refers to precise knockout or knockin (introducing an exogenous gene) at any fixed gene locus. Now CRISPR/Cas9 and TALEN are the most frequently used gene editing technologies. Although gene editing has been widely applied in model organisms ${ }^{[111,112]}$, the reports for aquatic animals are very limited with no report for marine fish. In Atlantic salmon, juvenile fish with tyrosinase and SLC45A2 mutations were obtained by CRISPR/Cas9 technology ${ }^{[113]}$. In China, a research team from Southwest University established CRISPR/Cas9 and TALEN technology in tilapia, and knocked out a number of genes related to sex determination/differentiation. These mutants provided powerful resources for studying the mechanism of sex determination/differentiation ${ }^{[114]}$. Gene editing has been initiated in common carp, in order to obtain a mutant with fewer intermuscular bones. In comparison, gene editing of marine fish has been more difficult from a technical perspective, e.g., the fragile egg membrane. In China, YSFRI scientists have applied CRISPR/Cas9 and TALEN in marine flatfish and obtained a half-smooth tongue sole with $d m r t 1$ mutation. The gonad of the mutant showed an ovarian-like structure although it was a genetic male, further suggesting $d m r t 1$ is the male determining gene in half-smooth tongue sole ${ }^{[70]}$.

\section{Conclusions and prospects}

Aquatic genomic and molecular breeding is one of the most active areas in contemporary fishery research, and it is also the direction with the most development potential. With the increasing numbers of deciphered aquatic genomes, international research on aquatic biotechnology will turn to functional genomics and its application. We proposed that the following five aspects would be main research focuses in the next few years and also the fields where breakthroughs are most likely to take place.

\subsection{Genetic dissection of important economic traits in aquaculture animals will become the focus of basic research}

At present, some sex determination genes in fish have been identified and the mechanism has been understood to a certain extent. Whereas in most fish and other aquatic animals, major genes related to economic traits have not been identified, and the understandings of regulatory mechanisms for sex determination, disease resistance, stress resistance, environmental adaptation, reproduction and development are quite limited. Whole genome sequencing in many important aquatic animals has provided a massive genetic resource to identify traitrelated genes and clarify their regulatory mechanisms.

\subsection{Molecular marker assisted sex control technology will remain important in aquaculture}

Obvious sexual dimorphism during growth increases the importance of sex control technology in aquatic animals. During the period of the 12th Five-Year Plan, with the support of the Special Fund for Agro-Scientific Research in the Public Interest (Project: Research on fish sex control and monosexual fry breeding techniques), the study of sex specific marker screening, artificial gynogenesis and sex control technology has been carried out in eight important cultured fish of China. The project's achievements have provided valuable experience for developing sex control technology for aquatic animals. With the increasing number of aquatic genomes completed, the screening of sex-specific markers has become more feasible. It is speculated that genetic sex identification and molecular marker assisted sex control will become a new trend in aquatic sex control field.

\subsection{Genome wide selective breeding will become a new tendency in aquatic breeding}

Based on whole genome SNP markers, genome-wide selective breeding could facilitate the simultaneous selection of multiple traits, e.g., high yield, disease resistance, stress resistance and high quality. This method is especially suitable for low heritable traits such as disease and stress resistance, and therefore shows great potential for productive application with prospects for broader use in agricultural breeding. It has been successfully used for producing improved lines in a number of crops and livestock. During the 12th Five-Year Plan, with the support of the National High-Tech R\&D Program of China, Chinese scientists have successfully applied this technique to scallop (two new lines were approved, Haidajinbei of 
Yesso scallop and Haifeng 12 of Bay scallop), half-smooth tongue sole and large yellow croaker ${ }^{[115,116]}$, consolidating that the advanced technology is suitable for aquatic animals. With more aquatic genomes being sequenced, it is predicted that the genome-wide selective breeding will become an effective approach, which widely used in breeding of aquatic animals.

\subsection{Gene editing will become a new tool for genetic improvement in aquatic animals}

In life sciences, gene editing is the greatest technological development in genetic manipulation of this century, and is also one of the most promising technologies for breeding. With the development and optimization of gene knockout and knockin (TALEN and CRISPR/Cas9) technologies, gene function can be revealed and effectively utilized. Although there are still difficulties for its application in marine aquaculture animals, the recent success of TALEN in half-smooth tongue sole has demonstrated its potential for use for marine animals.

\subsection{Multi-omics will become the new research method}

With the rapid development of genomic research, the combination of genome, transcriptome, proteome, metabolome and epigenome will become the new research methods to explore and dissect the mysteries and principles of life. To reveal the mechanisms underlying economic traits, such as high yield, disease resistance, stress resistance, and high quality, a combination of static genomic data, with dynamic proteomic, transcriptomic, epigenetic and metabolomic data are required. This multiomics approach has been rarely reported for aquatic animals and the accomplishment of more aquatic genome sequencing and other-omes- would benefit multi-omics study. It can be predicted that multi-omics will have an important role in elucidating the molecular mechanism of important economic traits leading to the establishment of multi-omics breeding technology in the near future.

Acknowledgements We thank Prof. Qisheng Tang for his correction of this paper. This work was supported by grants from the National Natural Science Foundation of China $(31461163005,31530078)$ and the Taishan Scholar Climbing Project Fund of Shandong of China.

Compliance with ethics guidelines Wenteng Xu and Songlin Chen declare that they have no conflicts of interest or financial conflicts to disclose.

This article is a review and does not contain any studies with human or animal subjects performed by any of the authors.

\section{References}

1. Aparicio S, Chapman J, Stupka E, Putnam N, Chia J M, Dehal P, Christoffels A, Rash S, Hoon S, Smit A, Gelpke M D, Roach J, Oh T, Ho I Y, Wong M, Detter C, Verhoef F, Predki P, Tay A, Lucas S,
Richardson P, Smith S F, Clark M S, Edwards Y J, Doggett N, Zharkikh A, Tavtigian S V, Pruss D, Barnstead M, Evans C, Baden H, Powell J, Glusman G, Rowen L, Hood L, Tan Y H, Elgar G, Hawkins T, Venkatesh B, Rokhsar D, Brenner S. Whole-genome shotgun assembly and analysis of the genome of Fugu rubripes. Science, 2002, 297(5585): 1301-1310

2. Star B, Nederbragt A J, Jentoft S, Grimholt U, Malmstrøm M, Gregers T F, Rounge T B, Paulsen J, Solbakken M H, Sharma A, Wetten O F, Lanzén A, Winer R, Knight J, Vogel J H, Aken B, Andersen O, Lagesen K, Tooming-Klunderud A, Edvardsen R B, Tina K G, Espelund M, Nepal C, Previti C, Karlsen B O, Moum T, Skage M, Berg P R, Gjøen T, Kuhl H, Thorsen J, Malde K, Reinhardt R, Du L, Johansen S D, Searle S, Lien S, Nilsen F, Jonassen I, Omholt S W, Stenseth N C, Jakobsen K S. The genome sequence of Atlantic cod reveals a unique immune system. Nature, 2011, 477(7363): 207-210

3. Jones F C, Grabherr M G, Chan Y F, Russell P, Mauceli E, Johnson J, Swofford R, Pirun M, Zody M C, White S, Birney E, Searle S, Schmutz J, Grimwood J, Dickson M C, Myers R M, Miller C T, Summers B R, Knecht A K, Brady S D, Zhang H, Pollen A A, Howes T, Amemiya C, Baldwin J, Bloom T, Jaffe D B, Nicol R, Wilkinson J, Lander E S, Di Palma F, Lindblad-Toh K, Kingsley D M. The genomic basis of adaptive evolution in threespine sticklebacks. Nature, 2012, 484(7392): 55-61

4. Howe K, Clark M D, Torroja C F, Torrance J, Berthelot C, Muffato M, Collins J E, Humphray S, McLaren K, Matthews L, McLaren S, Sealy I, Caccamo M, Churcher C, Scott C, Barrett J C, Koch R, Rauch G J, White S, Chow W, Kilian B, Quintais L T, GuerraAssunção J A, Zhou Y, Gu Y, Yen J, Vogel J H, Eyre T, Redmond S, Banerjee R, Chi J, Fu B, Langley E, Maguire S F, Laird G K, Lloyd D, Kenyon E, Donaldson S, Sehra H, Almeida-King J, Loveland J, Trevanion S, Jones M, Quail M, Willey D, Hunt A, Burton J, Sims S, McLay K, Plumb B, Davis J, Clee C, Oliver K, Clark R, Riddle C, Elliot D, Threadgold G, Harden G, Ware D, Begum S, Mortimore B, Kerry G, Heath P, Phillimore B, Tracey A, Corby N, Dunn M, Johnson C, Wood J, Clark S, Pelan S, Griffiths G, Smith M, Glithero R, Howden P, Barker N, Lloyd C, Stevens C, Harley J, Holt K, Panagiotidis G, Lovell J, Beasley H, Henderson C, Gordon D, Auger K, Wright D, Collins J, Raisen C, Dyer L, Leung K, Robertson L, Ambridge K, Leongamornlert D, McGuire S, Gilderthorp R, Griffiths C, Manthravadi D, Nichol S, Barker G, Whitehead S, Kay M, Brown J, Murnane C, Gray E, Humphries M, Sycamore N, Barker D, Saunders D, Wallis J, Babbage A, Hammond S, Mashreghi-Mohammadi M, Barr L, Martin S, Wray P, Ellington A, Matthews N, Ellwood M, Woodmansey R, Clark G, Cooper J, Tromans A, Grafham D, Skuce C, Pandian R, Andrews R, Harrison E, Kimberley A, Garnett J, Fosker N, Hall R, Garner P, Kelly D, Bird C, Palmer S, Gehring I, Berger A, Dooley C M, Ersan-Ürün Z, Eser C, Geiger H, Geisler M, Karotki L, Kirn A, Konantz J, Konantz M, Oberländer M, Rudolph-Geiger S, Teucke M, Lanz C, Raddatz G, Osoegawa K, Zhu B, Rapp A, Widaa S, Langford C, Yang F, Schuster S C, Carter N P, Harrow J, Ning Z, Herrero J, Searle S M, Enright A, Geisler R, Plasterk R H, Lee C, Westerfield M, de Jong P J, Zon L I, Postlethwait J H, NüssleinVolhard C, Hubbard T J, Roest Crollius H, Rogers J, Stemple D L. The zebrafish reference genome sequence and its relationship to the 
human genome. Nature, 2013, 496(7446): 498-503

5. Berthelot $C$, Brunet $F$, Chalopin D, Juanchich A, Bernard M, Noël B, Bento P, Da Silva C, Labadie K, Alberti A, Aury J M, Louis A, Dehais P, Bardou P, Montfort J, Klopp C, Cabau C, Gaspin C, Thorgaard G H, Boussaha M, Quillet E, Guyomard R, Galiana D, Bobe J, Volff J N, Genêt C, Wincker P, Jaillon O, Crollius H R, Guiguen $Y$. The rainbow trout genome provides novel insights into evolution after whole-genome duplication in vertebrates. Nature Communications, 2014, 5: 3657

6. Lien S, Koop B F, Sandve S R, Miller J R, Kent M P, Nome T, Hvidsten T R, Leong J S, Minkley D R, Zimin A, Grammes F, Grove H, Gjuvsland A, Walenz B, Hermansen R A, von Schalburg K, Rondeau E B, Di Genova A, Samy J K A, Olav Vik J, Vigeland $\mathrm{M} \mathrm{D}$, Caler L, Grimholt U, Jentoft S, Inge Våge $\mathrm{D}$, de Jong $\mathrm{P}$, Moen T, Baranski M, Palti Y, Smith D R, Yorke J A, Nederbragt A J, Tooming-Klunderud A, Jakobsen K S, Jiang X, Fan D, Hu Y, Liberles D A, Vidal R, Iturra P, Jones S J M, Jonassen I, Maass A, Omholt S W, Davidson W S. The Atlantic salmon genome provides insights into rediploidization. Nature, 2016, 533(7602): 200-205

7. Zhang G, Fang X, Guo X, Li L, Luo R, Xu F, Yang P, Zhang L, Wang X, Qi H, Xiong Z, Que H, Xie Y, Holland P W, Paps J, Zhu Y, Wu F, Chen Y, Wang J, Peng C, Meng J, Yang L, Liu J, Wen B, Zhang N, Huang Z, Zhu Q, Feng Y, Mount A, Hedgecock D, Xu Z, Liu Y, Domazet-Lošo T, Du Y, Sun X, Zhang S, Liu B, Cheng P, Jiang X, Li J, Fan D, Wang W, Fu W, Wang T, Wang B, Zhang J, Peng Z, Li Y, Li N, Wang J, Chen M, He Y, Tan F, Song X, Zheng Q, Huang R, Yang H, Du X, Chen L, Yang M, Gaffney P M, Wang S, Luo L, She Z, Ming Y, Huang W, Zhang S, Huang B, Zhang Y, Qu T, Ni P, Miao G, Wang J, Wang Q, Steinberg C E, Wang H, Li N, Qian L, Zhang G, Li Y, Yang H, Liu X, Wang J, Yin Y, Wang J. The oyster genome reveals stress adaptation and complexity of shell formation. Nature, 2012, 490(7418): 49-54

8. Chen S, Zhang G, Shao C, Huang Q, Liu G, Zhang P, Song W, An N, Chalopin D, Volff J N, Hong Y, Li Q, Sha Z, Zhou H, Xie M, Yu Q, Liu Y, Xiang H, Wang N, Wu K, Yang C, Zhou Q, Liao X, Yang L, Hu Q, Zhang J, Meng L, Jin L, Tian Y, Lian J, Yang J, Miao G, Liu S, Liang Z, Yan F, Li Y, Sun B, Zhang H, Zhang J, Zhu Y, Du M, Zhao Y, Schartl M, Tang Q, Wang J. Whole-genome sequence of a flatfish provides insights into $\mathrm{ZW}$ sex chromosome evolution and adaptation to a benthic lifestyle. Nature Genetics, 2014, 46(3): 253-260

9. Xu P, Zhang X, Wang X, Li J, Liu G, Kuang Y, Xu J, Zheng X, Ren L, Wang G, Zhang Y, Huo L, Zhao Z, Cao D, Lu C, Li C, Zhou Y, Liu Z, Fan Z, Shan G, Li X, Wu S, Song L, Hou G, Jiang Y, Jeney Z, Yu D, Wang L, Shao C, Song L, Sun J, Ji P, Wang J, Li Q, Xu L, Sun F, Feng J, Wang C, Wang S, Wang B, Li Y, Zhu Y, Xue W, Zhao L, Wang J, Gu Y, Lv W, Wu K, Xiao J, Wu J, Zhang $\mathrm{Z}$, Yu J, Sun X. Genome sequence and genetic diversity of the common carp, Cyprinus carpio. Nature Genetics, 2014, 46(11): $1212-1219$

10. Wu C, Zhang D, Kan M, Lv Z, Zhu A, Su Y, Zhou D, Zhang J, Zhang Z, Xu M, Jiang L, Guo B, Wang T, Chi C, Mao Y, Zhou J, Yu X, Wang H, Weng X, Jin J G, Ye J, He L, Liu Y. The draft genome of the large yellow croaker reveals well-developed innate immunity. Nature Communications, 2014, 5: 5227
11. Wang Y, Lu Y, Zhang Y, Ning Z, Li Y, Zhao Q, Lu H, Huang R, Xia X, Feng Q, Liang X, Liu K, Zhang L, Lu T, Huang T, Fan D, Weng Q, Zhu C, Lu Y, Li W, Wen Z, Zhou C, Tian Q, Kang X, Shi M, Zhang W, Jang S, Du F, He S, Liao L, Li Y, Gui B, He H, Ning Z, Yang C, He L, Luo L, Yang R, Luo Q, Liu X, Li S, Huang W, Xiao L, Lin H, Han B, Zhu Z. The draft genome of the grass carp (Ctenopharyngodon idellus) provides insights into its evolution and vegetarian adaptation. Nature Genetics, 2015, 47(6): 625631

12. Jaillon O, Aury J M, Brunet F, Petit J L, Stange-Thomann N, Mauceli E, Bouneau L, Fischer C, Ozouf-Costaz C, Bernot A, Nicaud S, Jaffe D, Fisher S, Lutfalla G, Dossat C, Segurens B, Dasilva C, Salanoubat M, Levy M, Boudet N, Castellano S, Anthouard V, Jubin C, Castelli V, Katinka M, Vacherie B, Biémont C, Skalli Z, Cattolico L, Poulain J, De Berardinis V, Cruaud C, Duprat S, Brottier P, Coutanceau J P, Gouzy J, Parra G, Lardier G, Chapple C, McKernan K J, McEwan P, Bosak S, Kellis M, Volff J N, Guigó R, Zody M C, Mesirov J, Lindblad-Toh K, Birren B, Nusbaum C, Kahn D, Robinson-Rechavi M, Laudet V, Schachter V, Quétier F, Saurin W, Scarpelli C, Wincker P, Lander E S, Weissenbach J, Roest Crollius H. Genome duplication in the teleost fish Tetraodon nigroviridis reveals the early vertebrate proto-karyotype. Nature, 2004, 431(7011): 946-957

13. Kasahara M, Naruse K, Sasaki S, Nakatani Y, Qu W, Ahsan B, Yamada T, Nagayasu Y, Doi K, Kasai Y, Jindo T, Kobayashi D, Shimada A, Toyoda A, Kuroki Y, Fujiyama A, Sasaki T, Shimizu A, Asakawa S, Shimizu N, Hashimoto S, Yang J, Lee Y, Matsushima K, Sugano S, Sakaizumi M, Narita T, Ohishi K, Haga S, Ohta F, Nomoto H, Nogata K, Morishita T, Endo T, Shin-I T, Takeda H, Morishita S, Kohara Y. The medaka draft genome and insights into vertebrate genome evolution. Nature, 2007, 447 (7145): 714-719

14. Liu Z, Liu S, Yao J, Bao L, Zhang J, Li Y, Jiang C, Sun L, Wang R, Zhang Y, Zhou T, Zeng Q, Fu Q, Gao S, Li N, Koren S, Jiang Y, Zimin A, Xu P, Phillippy A M, Geng X, Song L, Sun F, Li C, Wang X, Chen A, Jin Y, Yuan Z, Yang Y, Tan S, Peatman E, Lu J, Qin Z, Dunham R, Li Z, Sonstegard T, Feng J, Danzmann R G, Schroeder S, Scheffler B, Duke M V, Ballard L, Kucuktas H, Kaltenboeck L, Liu H, Armbruster J, Xie Y, Kirby M L, Tian Y, Flanagan M E, Mu W, Waldbieser G C. The channel catfish genome sequence provides insights into the evolution of scale formation in teleosts. Nature Communications, 2016, 7: 11757

15. Takeuchi T, Kawashima T, Koyanagi R, Gyoja F, Tanaka M, Ikuta T, Shoguchi E, Fujiwara M, Shinzato C, Hisata K, Fujie M, Usami T, Nagai K, Maeyama K, Okamoto K, Aoki H, Ishikawa T, Masaoka T, Fujiwara A, Endo K, Endo H, Nagasawa H, Kinoshita S, Asakawa S, Watabe S, Satoh N. Draft genome of the pearl oyster Pinctada fucata: a platform for understanding bivalve biology. DNA Research, 2012, 19(2): 117-130

16. Smith J J, Kuraku S, Holt C, Sauka-Spengler T, Jiang N, Campbell M S, Yandell M D, Manousaki T, Meyer A, Bloom O E, Morgan J R, Buxbaum J D, Sachidanandam R, Sims C, Garruss A S, Cook M, Krumlauf R, Wiedemann L M, Sower S A, Decatur W A, Hall J A, Amemiya C T, Saha N R, Buckley K M, Rast J P, Das S, Hirano M, McCurley N, Guo P, Rohner N, Tabin C J, Piccinelli P, Elgar G, Ruffier M, Aken B L, Searle S M, Muffato M, Pignatelli M, 
Herrero J, Jones M, Brown C T, Chung-Davidson Y W, Nanlohy K G, Libants S V, Yeh C Y, McCauley D W, Langeland J A, Pancer Z, Fritzsch B, de Jong P J, Zhu B, Fulton L L, Theising B, Flicek P, Bronner M E, Warren W C, Clifton S W, Wilson R K, Li W. Sequencing of the sea lamprey (Petromyzon marinus) genome provides insights into vertebrate evolution. Nature Genetics, 2013, 45(4): 415-421, 421e411-412

17. Amemiya C T, Alföldi J, Lee A P, Fan S, Philippe H, Maccallum I, Braasch I, Manousaki T, Schneider I, Rohner N, Organ C, Chalopin D, Smith J J, Robinson M, Dorrington R A, Gerdol M, Aken B, Biscotti M A, Barucca M, Baurain D, Berlin A M, Blatch G L, Buonocore F, Burmester T, Campbell M S, Canapa A, Cannon J P, Christoffels A, De Moro G, Edkins A L, Fan L, Fausto A M, Feiner N, Forconi M, Gamieldien J, Gnerre S, Gnirke A, Goldstone J V, Haerty W, Hahn M E, Hesse U, Hoffmann S, Johnson J, Karchner S I, Kuraku S, Lara M, Levin J Z, Litman G W, Mauceli E, Miyake T, Mueller M G, Nelson D R, Nitsche A, Olmo E, Ota T, Pallavicini A, Panji S, Picone B, Ponting C P, Prohaska S J, Przybylski D, Saha N R, Ravi V, Ribeiro F J, SaukaSpengler T, Scapigliati G, Searle S M, Sharpe T, Simakov O, Stadler P F, Stegeman J J, Sumiyama K, Tabbaa D, Tafer H, Turner-Maier J, van Heusden P, White S, Williams L, Yandell M, Brinkmann H, Volff J N, Tabin C J, Shubin N, Schartl M, Jaffe D B, Postlethwait J H, Venkatesh B, Di Palma F, Lander E S, Meyer A, Lindblad-Toh K. The African coelacanth genome provides insights into tetrapod evolution. Nature, 2013, 496(7445): 311316

18. Nakamura Y, Mori K, Saitoh K, Oshima K, Mekuchi M, Sugaya T, Shigenobu Y, Ojima N, Muta S, Fujiwara A, Yasuike M, Oohara I, Hirakawa H, Chowdhury V S, Kobayashi T, Nakajima K, Sano M, Wada T, Tashiro K, Ikeo K, Hattori M, Kuhara S, Gojobori T, Inouye K. Evolutionary changes of multiple visual pigment genes in the complete genome of Pacific bluefin tuna. Proceedings of the National Academy of Sciences of the United States of America, 2013, 110(27): 11061-11066

19. Schartl M, Walter R B, Shen Y, Garcia T, Catchen J, Amores A, Braasch I, Chalopin D, Volff J N, Lesch K P, Bisazza A, Minx P, Hillier L, Wilson R K, Fuerstenberg S, Boore J, Searle S, Postlethwait J H, Warren W C. The genome of the platyfish, Xiphophorus maculatus, provides insights into evolutionary adaptation and several complex traits. Nature Genetics, 2013, 45 (5): 567-572

20. Wang Z, Pascual-Anaya J, Zadissa A, Li W, Niimura Y, Huang Z, Li C, White S, Xiong Z, Fang D, Wang B, Ming Y, Chen Y, Zheng Y, Kuraku S, Pignatelli M, Herrero J, Beal K, Nozawa M, Li Q, Wang J, Zhang H, Yu L, Shigenobu S, Wang J, Liu J, Flicek P, Searle S, Wang J, Kuratani S, Yin Y, Aken B, Zhang G, Irie N. The draft genomes of soft-shell turtle and green sea turtle yield insights into the development and evolution of the turtle-specific body plan. Nature Genetics, 2013, 45(6): 701-706

21. Venkatesh B, Lee A P, Ravi V, Maurya A K, Lian M M, Swann J B, Ohta Y, Flajnik M F, Sutoh Y, Kasahara M, Hoon S, Gangu V, Roy S W, Irimia M, Korzh V, Kondrychyn I, Lim Z W, Tay B H, Tohari S, Kong K W, Ho S, Lorente-Galdos B, Quilez J, MarquesBonet T, Raney B J, Ingham P W, Tay A, Hillier L W, Minx P, Boehm T, Wilson R K, Brenner S, Warren W C. Elephant shark genome provides unique insights into gnathostome evolution. Nature, 2014, 505(7482): 174-179

22. Shin S C, Ahn D H, Kim S J, Pyo C W, Lee H, Kim M K, Lee J, Lee J E, Detrich H W, Postlethwait J H, Edwards D, Lee S G, Lee J H, Park H. The genome sequence of the Antarctic bullhead notothen reveals evolutionary adaptations to a cold environment. Genome Biology, 2014, 15(9): 468

23. You X, Bian C, Zan Q, Xu X, Liu X, Chen J, Wang J, Qiu Y, Li W, Zhang X, Sun Y, Chen S, Hong W, Li Y, Cheng S, Fan G, Shi C, Liang J, Tom Tang Y, Yang C, Ruan Z, Bai J, Peng C, Mu Q, Lu J, Fan M, Yang S, Huang Z, Jiang X, Fang X, Zhang G, Zhang Y, Polgar G, Yu H, Li J, Liu Z, Zhang G, Ravi V, Coon S L, Wang J, Yang H, Venkatesh B, Wang J, Shi Q. Mudskipper genomes provide insights into the terrestrial adaptation of amphibious fishes. Nature Communications, 2014, 5: 5594

24. Ao J, Mu Y, Xiang L X, Fan D, Feng M, Zhang S, Shi Q, Zhu L Y, Li T, Ding Y, Nie L, Li Q, Dong W R, Jiang L, Sun B, Zhang X, Li M, Zhang H Q, Xie S, Zhu Y, Jiang X, Wang X, Mu P, Chen W, Yue Z, Wang Z, Wang J, Shao J Z, Chen X. Genome sequencing of the perciform fish Larimichthys crocea provides insights into molecular and genetic mechanisms of stress adaptation. PLoS Genetics, 2015, 11(4): e1005118

25. Gao Y, Gao Q, Zhang H, Wang L, Zhang F, Yang C, Song L. Draft sequencing and analysis of the genome of pufferfish Takifugu flavidus. DNA Research, 2014, 21(6): 627-637

26. Reichwald K, Petzold A, Koch P, Downie B R, Hartmann N, Pietsch S, Baumgart M, Chalopin D, Felder M, Bens M, Sahm A, Szafranski K, Taudien S, Groth M, Arisi I, Weise A, Bhatt S S, Sharma V, Kraus J M, Schmid F, Priebe S, Liehr T, Görlach M, Than M E, Hiller M, Kestler H A, Volff J N, Schartl M, Cellerino A, Englert C, Platzer M. Insights into sex chromosome evolution and aging from the genome of a short-lived fish. Cell, 2015, 163 (6): $1527-1538$

27. AlMomin S, Kumar V, Al-Amad S, Al-Hussaini M, Dashti T, AlEnezi K, Akbar A, Golding B. Draft genome sequence of the silver pomfret fish, Pampus argenteus. Genome, 2016, 59(1): 51-58

28. Braasch I, Gehrke A R, Smith J J, Kawasaki K, Manousaki T, Pasquier J, Amores A, Desvignes T, Batzel P, Catchen J, Berlin A M, Campbell M S, Barrell D, Martin K J, Mulley J F, Ravi V, Lee A P, Nakamura T, Chalopin D, Fan S, Wcisel D, Cañestro C, Sydes J, Beaudry F E, Sun Y, Hertel J, Beam M J, Fasold M, Ishiyama M, Johnson J, Kehr S, Lara M, Letaw J H, Litman G W, Litman R T, Mikami M, Ota T, Saha N R, Williams L, Stadler P F, Wang H, Taylor J S, Fontenot Q, Ferrara A, Searle S M, Aken B, Yandell M, Schneider I, Yoder J A, Volff J N, Meyer A, Amemiya C T, Venkatesh B, Holland P W, Guiguen Y, Bobe J, Shubin N H, Di Palma F, Alföldi J, Lindblad-Toh K, Postlethwait J H. The spotted gar genome illuminates vertebrate evolution and facilitates humanteleost comparisons. Nature Genetics, 2016, 48(4): 427-437

29. Song W, Pang R, Niu Y, Gao F, Zhao Y, Zhang J, Sun J, Shao C, Liao X, Wang L, Tian Y, Chen S. Construction of high-density genetic linkage maps and mapping of growth-related quantitative trail loci in the Japanese flounder (Paralichthys olivaceus). PLoS One, 2012, 7(11): e50404

30. Shao C, Niu Y, Rastas P, Liu Y, Xie Z, Li H, Wang L, Jiang Y, Tai S, Tian Y, Sakamoto T, Chen S. Genome-wide SNP identification 
for the construction of a high-resolution genetic map of Japanese flounder (Paralichthys olivaceus): applications to QTL mapping of Vibrio anguillarum disease resistance and comparative genomic analysis. DNA Research, 2015, 22(2): 161-170

31. Song W, Li Y, Zhao Y, Liu Y, Niu Y, Pang R, Miao G, Liao X, Shao C, Gao F, Chen S. Construction of a high-density microsatellite genetic linkage map and mapping of sexual and growth-related traits in half-smooth tongue sole (Cynoglossus semilaevis). PLoS One, 2012, 7(12): e52097

32. Zhang X, Zhang Y, Zheng X, Kuang Y, Zhao Z, Zhao L, Li C, Jiang L, Cao D, Lu C, Xu P, Sun X. A consensus linkage map provides insights on genome character and evolution in common carp (Cyprinus carpio L.). Marine Biotechnology, 2013, 15(3): 275-312

33. Li Y, Liu S, Qin Z, Waldbieser G, Wang R, Sun L, Bao L, Danzmann R G, Dunham R, Liu Z. Construction of a high-density, high-resolution genetic map and its integration with BAC-based physical map in channel catfish. DNA Research, 2015, 22(1): 3952

34. Guyomard R, Boussaha M, Krieg F, Hervet C, Quillet E. A synthetic rainbow trout linkage map provides new insights into the salmonid whole genome duplication and the conservation of synteny among teleosts. BMC Genetics, 2012, 13(1): 15

35. Bouza C, Hermida M, Pardo B G, Vera M, Fernández C, de la Herrán R, Navajas-Pérez R, Álvarez-Dios J A, GÁmez-Tato A, Martínez P. An Expressed Sequence Tag (EST)-enriched genetic map of turbot (Scophthalmus maximus): a useful framework for comparative genomics across model and farmed teleosts. BMC Genetics, 2012, 13(1): 54

36. Wang W, Hu Y, Ma Y, Xu L, Guan J, Kong J. High-density genetic linkage mapping in turbot (Scophthalmus maximus L.) based on SNP markers and major sex- and growth-related regions detection. PLoS One, 2015, 10(3): e0120410

37. Xia J, Wan Z, Ng Z, Wang L, Fu G, Lin G, Liu F, Yue G. Genomewide discovery and in silico mapping of gene-associated snps in Nile tilapia. Aquaculture, 2014, 432: 67-73

38. Gonen S, Lowe N R, Cezard T, Gharbi K, Bishop S C, Houston R D. Linkage maps of the Atlantic salmon (Salmo salar) genome derived from RAD sequencing. BMC Genomics, 2014, 15(1): 166

39. Ao J, Li J, You X, Mu Y, Ding Y, Mao K, Bian C, Mu P, Shi Q, Chen $\mathrm{X}$. Construction of the high-density genetic linkage map and chromosome map of large yellow croaker (Larimichthys crocea). International Journal of Molecular Sciences, 2015, 16(11): 26237-26248

40. Xiao S, Wang P, Zhang Y, Fang L, Liu Y, Li J T, Wang Z Y. Gene map of large yellow croaker (Larimichthys crocea) provides insights into teleost genome evolution and conserved regions associated with growth. Scientific Reports, 2015, 5(1): 18661

41. Guo W J, Tong J G, Yu X M, Zhu C K, Feng X, Fu B D, He S P, Zeng F Z, Wang X H, Liu H Y, Liu L S. A second generation genetic linkage map for silver carp (Hypophthalmichehys molitrix) using microsatellite markers. Aquaculture, 2013, 412: 97-106

42. Zhu C, Tong J, Yu X, Guo W, Wang X, Liu H, Feng X, Sun Y, Liu $\mathrm{L}, \mathrm{Fu}$ B. A second-generation genetic linkage map for bighead carp (Aristichthys nobilis) based on microsatellite markers. Animal Genetics, 2014, 45(5): 699-708
43. You X, Shu L, Li S, Chen J, Luo J, Lu J, Mu Q, Bai J, Xia Q, Chen Q, Cai Y, Zhang H, Chen G, Lin H, Zhang Y, Shi Q. Construction of high-density genetic linkage maps for orange-spotted grouper Epinephelus coioides using multiplexed shotgun genotyping. BMC Genetics, 2013, 14(1): 113

44. Palaiokostas C, Bekaert M, Taggart J B, Gharbi K, McAndrew B J, Chatain B, Penman D J, Vandeputte M. A new SNP-based vision of the genetics of sex determination in European sea bass (Dicentrarchus labrax). Genetics, Selection, Evolution, 2015, 47 (1): 68

45. Hollenbeck C M, Portnoy D S, Gold J R. A genetic linkage map of red drum (Sciaenops ocellatus) and comparison of chromosomal syntenies with four other fish species. Aquaculture, 2015, 435: 265-274

46. Li H, Liu X, Zhang G. A consensus microsatellite-based linkage map for the hermaphroditic bay scallop (Argopecten irradians) and its application in size-related QTL analysis. PLoS One, 2012, 7 (10): e46926

47. Jiao W, Fu X, Dou J, Li H, Su H, Mao J, Yu Q, Zhang L, Hu X, Huang X, Wang Y, Wang S, Bao Z. High-resolution linkage and quantitative trait locus mapping aided by genome survey sequencing: building up an integrative genomic framework for a bivalve mollusc. DNA Research, 2014, 21(1): 85-101

48. Yu Y, Zhang X, Yuan J, Li F, Chen X, Zhao Y, Huang L, Zheng H, Xiang J. Genome survey and high-density genetic map construction provide genomic and genetic resources for the Pacific White Shrimp Litopenaeus vannamei. Scientific Reports, 2015, 5: 15612

49. Geng X, Sha J, Liu S, Bao L, Zhang J, Wang R, Yao J, Li C, Feng J, Sun F, Sun L, Jiang C, Zhang Y, Chen A, Dunham R, Zhi D, Liu Z. A genome-wide association study in catfish reveals the presence of functional hubs of related genes within QTLs for columnaris disease resistance. BMC Genomics, 2015, 16(1): 196

50. Xia J H, Feng F, Lin G, Wang C M, Yue G H. A first generation BAC-based physical map of the Asian seabass (Lates calcarifer). PLoS One, 2010, 5(8): e11974

51. Ng S H, Artieri C G, Bosdet I E, Chiu R, Danzmann R G, Davidson W S, Ferguson M M, Fjell C D, Hoyheim B, Jones S J, de Jong P J, Koop B F, Krzywinski M I, Lubieniecki K, Marra M A, Mitchell L A, Mathewson C, Osoegawa K, Parisotto S E, Phillips R B, Rise M L, von Schalburg K R, Schein J E, Shin H, Siddiqui A, Thorsen J, Wye N, Yang G, Zhu B. A physical map of the genome of Atlantic salmon, Salmo salar. Genomics, 2005, 86(4): 396-404

52. Quiniou S M, Waldbieser G C, Duke M V. A first generation BACbased physical map of the channel catfish genome. $B M C$ Genomics, 2007, 8(1): 40

53. Xu P, Wang S, Liu L, Thorsen J, Kucuktas H, Liu Z. A BAC-based physical map of the channel catfish genome. Genomics, 2007, 90 (3): 380-388

54. Xu P, Wang J, Wang J, Cui R, Li Y, Zhao Z, Ji P, Zhang Y, Li J, Sun $X$. Generation of the first BAC-based physical map of the common carp genome. BMC Genomics, 2011, 12(1): 537

55. Zhang J, Shao C, Zhang L, Liu K, Gao F, Dong Z, Xu P, Chen S. A first generation BAC-based physical map of the half-smooth tongue sole (Cynoglossus semilaevis) genome. BMC Genomics, 2014, 15(1): 215

56. Palti Y, Luo M C, Hu Y, Genet C, You F M, Vallejo R L, 
Thorgaard G H, Wheeler P A, Rexroad C E 3rd. A first generation BAC-based physical map of the rainbow trout genome. $B M C$ Genomics, 2009, 10(1): 462

57. Khorasani M Z, Hennig S, Imre G, Asakawa S, Palczewski S, Berger A, Hori H, Naruse K, Mitani H, Shima A, Lehrach H, Wittbrodt J, Kondoh H, Shimizu N, Himmelbauer H. A first generation physical map of the medaka genome in BACs essential for positional cloning and clone-by-clone based genomic sequencing. Mechanisms of Development, 2004, 121(7-8): 903-913

58. Kingsley D M, Baoli Z, Osoegawa K, De Jong P J, Jacqueline S, Marra M, Catherine P, Amemiya C, Schluter D, Balabhadra S, Brian F, Yee Man C, Dickson M, Grimwood J, Schmutz J, Talbot W S, Myers R. New genomic tools for molecular studies of evolutionary change in threespine sticklebacks. Behaviour, 2004, 141(11-12): 1331-1344

59. Katagiri T, Kidd C, Tomasino E, Davis J T, Wishon C, Stern J E, Carleton K L, Howe A E, Kocher T D. A BAC-based physical map of the Nile tilapia genome. BMC Genomics, 2005, 6(1): 89

60. Zhang X, Zhao C, Huang C, Duan H, Huan P, Liu C, Zhang X, Zhang Y, Li F, Zhang H B, Xiang J. A BAC-based physical map of Zhikong scallop (Chlamys farreri Jones et Preston). PLoS One, 2011, 6(11): e27612

61. Xiao S, Li J, Ma F, Fang L, Xu S, Chen W, Wang Z Y. Rapid construction of genome map for large yellow croaker (Larimichthys crocea) by the whole-genome mapping in BioNano Genomics Irys system. BMC Genomics, 2015, 16(1): 670

62. Hattori R S, Murai Y, Oura M, Masuda S, Majhi S K, Sakamoto T, Fernandino J I, Somoza G M, Yokota M, Strüssmann C A. A Ylinked anti-Müllerian hormone duplication takes over a critical role in sex determination. Proceedings of the National Academy of Sciences of the United States of America, 2012, 109(8): 2955-2959

63. Santerre C, Sourdaine P, Adeline B, Martinez A S. Cg-SoxE and $\mathrm{Cg}-\beta$-catenin, two new potential actors of the sex-determining pathway in a hermaphrodite lophotrochozoan, the Pacific oyster Crassostrea gigas. Comparative Biochemistry and Physiology Part A: Molecular \& Integrative Physiology, 2014, 167: 68-76

64. Shen Z G, Wang H P. Molecular players involved in temperaturedependent sex determination and sex differentiation in Teleost fish. Genetics, Selection, Evolution, 2014, 46(1): 26

65. Takehana Y, Matsuda M, Myosho T, Suster M L, Kawakami K, Shin-I T, Kohara Y, Kuroki Y, Toyoda A, Fujiyama A, Hamaguchi S, Sakaizumi M, Naruse K. Co-option of Sox3 as the maledetermining factor on the $\mathrm{Y}$ chromosome in the fish Oryzias dancena. Nature Communications, 2014, 5: 4157

66. Yano A, Guyomard R, Nicol B, Jouanno E, Quillet E, Klopp C, Cabau C, Bouchez O, Fostier A, Guiguen Y. An immune-related gene evolved into the master sex-determining gene in rainbow trout, Oncorhynchus mykiss. Current Biology, 2012, 22(15): 14231428

67. Kamiya T, Kai W, Tasumi S, Oka A, Matsunaga T, Mizuno N, Fujita M, Suetake H, Suzuki S, Hosoya S, Tohari S, Brenner S, Miyadai T, Venkatesh B, Suzuki Y, Kikuchi K. A trans-species missense SNP in Amhr2 is associated with sex determination in the tiger pufferfish, Takifugu rubripes (fugu). PLoS Genetics, 2012, 8 (7): e1002798

68. Kikuchi K, Hamaguchi S. Novel sex-determining genes in fish and sex chromosome evolution. Developmental Dynamics, 2013, 242 (4): 339-353

69. Shao C, Li Q, Chen S, Zhang P, Lian J, Hu Q, Sun B, Jin L, Liu S, Wang Z, Zhao H, Jin Z, Liang Z, Li Y, Zheng Q, Zhang Y, Wang J, Zhang G. Epigenetic modification and inheritance in sexual reversal of fish. Genome Research, 2014, 24(4): 604-615

70. Chen S L, Cui Z K, Zheng H Q, Liu Y, Wang N, Li Y Z, Shao C W. A genome-editing based method for germplasm construction in marine flatfish and its application. China Patent ZL20161016 2019.5, 2016

71. Li M H, Yang H H, Li M R, Sun Y L, Jiang X L, Xie Q P, Wang T R, Shi H J, Sun L N, Zhou L Y, Wang D S. Antagonistic roles of Dmrt1 and Foxl2 in sex differentiation via estrogen production in tilapia as demonstrated by TALENs. Endocrinology, 2013, 154 (12): 4814-4825

72. Wang N, Wang X, Yang C, Zhao X, Zhang Y, Wang T, Chen S. Molecular cloning and multifunctional characterization of GRIM19 (gene associated with retinoid-interferon-induced mortality 19) homologue from turbot (Scophthalmus maximus). Developmental and Comparative Immunology, 2014, 43(1): 96-105

73. Yang C G, Liu S S, Sun B, Wang X L, Wang N, Chen S L. Ironmetabolic function and potential antibacterial role of Hepcidin and its correlated genes (Ferroportin 1 and Transferrin Receptor) in turbot (Scophthalmus maximus). Fish \& Shellfish Immunology, 2013, 34(3): 744-755

74. Zeng Y, Xiang J, Lu Y, Chen Y, Wang T, Gong G, Wang L, Li X, Chen S, Sha Z. sghC1q, a novel C1q family member from halfsmooth tongue sole (Cynoglossus semilaevis): identification, expression and analysis of antibacterial and antiviral activities. Developmental and Comparative Immunology, 2015, 48(1): 151163

75. Sha Z, Gong G, Wang S, Lu Y, Wang L, Wang Q, Chen S. Identification and characterization of Cynoglossus semilaevis microRNA response to Vibrio anguillarum infection through high-throughput sequencing. Developmental and Comparative Immunology, 2014, 44(1): 59-69

76. Hu G B, Lou H M, Dong X Z, Liu Q M, Zhang S C. Characteristics of the interferon regulatory factor 5 (IRF5) and its expression in response to LCDV and poly I:C challenges in Japanese flounder, Paralichthys olivaceus. Developmental and Comparative Immunology, 2012, 38(2): 377-382

77. Huang Y, Tan J M, Wang Z, Yin S W, Huang X, Wang W, Ren Q. Cloning and characterization of two different L-type lectin genes from the Chinese mitten crab Eriocheir sinensis. Developmental and Comparative Immunology, 2014, 46(2): 255-266

78. Liu Y, Zhang Y B, Liu T K, Gui J F. Lineage-specific expansion of IFIT gene family: an insight into coevolution with IFN gene family. PLoS One, 2013, 8(6): e66859

79. Wang B, Zhang Y B, Liu T K, Shi J, Sun F, Gui J F. Fish viperin exerts a conserved antiviral function through RLR-triggered IFN signaling pathway. Developmental and Comparative Immunology, 2014, 47(1): 140-149

80. Yao C L, Kong P, Wang Z Y, Ji P F, Liu X D, Cai M Y, Han X Z. Molecular cloning and expression of MyD88 in large yellow croaker, Pseudosciaena crocea. Fish \& Shellfish Immunology, 2009, 26(2): 249-255 
81. Huang X N, Wang Z Y, Yao C L. Characterization of Toll-like receptor 3 gene in large yellow croaker, Pseudosciaena crocea. Fish \& Shellfish Immunology, 2011, 31(1): 98-106

82. Han F, Wang X Q, Yao C L, Wang Z Y. Molecular characterization of Ran gene up-regulated in large yellow croaker (Pseudosciaena crocea) immunity. Fish \& Shellfish Immunology, 2010, 29(2): 327-333

83. Han F, Wang X, Yang Q, Cai M, Wang Z Y. Characterization of a RacGTPase up-regulated in the large yellow croaker Pseudosciaena crocea immunity. Fish \& Shellfish Immunology, 2011, 30 (2): 501-508

84. Mu Y, Wang K, Ao J, Chen X. Molecular characterization and biological effects of a CXCL8 homologue in large yellow croaker (Larimichthys crocea). Fish \& Shellfish Immunology, 2015, 44(2): $462-470$

85. Ao J, Mu Y, Wang K, Sun M, Wang X, Chen X. Identification and characterization of a novel Toll-like receptor 2 homologue in the large yellow croaker Larimichthys crocea. Fish \& Shellfish Immunology, 2016, 48: 221-227

86. Wu S, Li B, Lin H, Li W. Stimulatory effects of neuropeptide Y on the growth of orange-spotted grouper (Epinephelus coioides). General and Comparative Endocrinology, 2012, 179(2): 159-166

87. Ji X S, Chen S L, Jiang Y L, Xu T J, Yang J F, Tian Y S. Growth differences and differential expression analysis of pituitary adenylate cyclase activating polypeptide (PACAP) and growth hormone-releasing hormone (GHRH) between the sexes in halfsmooth tongue sole Cynoglossus semilaevis. General and Comparative Endocrinology, 2011, 170(1): 99-109

88. Ji X S, Liu H W, Chen S L, Jiang Y L, Tian Y S. Growth differences and dimorphic expression of growth hormone (GH) in female and male Cynoglossus semilaevis after male sexual maturation. Marine Genomics, 2011, 4(1): 9-16

89. Ma Q, Liu S, Zhuang Z, Lin L, Sun Z, Liu C, Ma H, Su Y, Tang Q. Genomic structure, polymorphism and expression analysis of the growth hormone $(\mathrm{GH})$ gene in female and male Half-smooth tongue sole (Cynoglossus semilaevis). Gene, 2012, 493(1): 92-104

90. Ma Q, Liu S F, Zhuang Z M, Sun Z Z, Liu C L, Tang Q S. The coexistence of two growth hormone receptors and their differential expression profiles between female and male tongue sole (Cynoglossus semilaevis). Gene, 2012, 511(2): 341-352

91. Qi X, Zhou W, Li S, Lu D, Yi S, Xie R, Liu X, Zhang Y, Lin H. Evidences for the regulation of GnRH and GTH expression by $\mathrm{GnIH}$ in the goldfish, Carassius auratus. Molecular and Cellular Endocrinology, 2013, 366(1): 9-20

92. Meng L, Zhu Y, Zhang N, Liu W, Liu Y, Shao C, Wang N, Chen S. Cloning and characterization of tesk1, a novel spermatogenesisrelated gene, in the tongue sole (Cynoglossus semilaevis). PLoS One, 2014, 9(10): e107922

93. Xu W, Li H, Dong Z, Cui Z, Zhang N, Meng L, Zhu Y, Liu Y, Li Y, Guo H, Ma J, Wei Z, Zhang N, Yang Y, Chen S. Ubiquitin ligase gene neurl3 plays a role in spermatogenesis of half-smooth tongue sole (Cynoglossus semilaevis) by regulating testis protein ubiquitination. Gene, 2016, 592(1): 215-220

94. Chen S L, Ji X S, Shao C W, Li W L, Yang J F, Liang Z, Liao X L, $\mathrm{Xu} \mathrm{G} \mathrm{B,} \mathrm{Xu} \mathrm{Y,} \mathrm{Song} \mathrm{W} \mathrm{T.} \mathrm{Induction} \mathrm{of} \mathrm{mitogynogenetic} \mathrm{diploids}$ and identification of WW super-female using sex-specific SSR markers in half-smooth tongue sole (Cynoglossus semilaevis). Marine Biotechnology, 2012, 14(1): 120-128

95. Langefors A, Lohm J, Grahn M, Andersen O, von Schantz T. Association between major histocompatibility complex class IIB alleles and resistance to Aeromonas salmonicida in Atlantic salmon. Proceedings: Biological Sciences, 2001, 268(1466): 479-485

96. Rodríguez-Ramilo S T, Fernández J, Toro M A, Bouza C, Hermida M, Fernández C, Pardo B G, Cabaleiro S, Martínez P. Uncovering QTL for resistance and survival time to Philasterides dicentrarchi in turbot (Scophthalmus maximus). Animal Genetics, 2013, 44(2): 149-157

97. Dutta S, Biswas S, Mukherjee K, Chakrabarty U, Mallik A, Mandal N. Identification of RAPD-SCAR marker linked to white spot syndrome virus resistance in populations of giant black tiger shrimp, Penaeus monodon Fabricius. Journal of Fish Diseases, 2014, 37(5): 471-480

98. Dutta S, Chakrabarty U, Mallik A, Mandal N. Experimental evidence for white spot syndrome virus (WSSV) susceptibility linked to a microsatellite DNA marker in giant black tiger shrimp, Penaeus monodon (Fabricius). Journal of Fish Diseases, 2013, 36 (6): 593-597

99. Campbell N R, LaPatra S E, Overturf K, Towner R, Narum S R. Association mapping of disease resistance traits in rainbow trout using restriction site associated DNA sequencing. G3: Genes, Genomes, Gnetics, 2014, 4(12): 2473-2481

100. Wang L, Fan C, Liu Y, Zhang Y, Liu S, Sun D, Deng H, Xu Y, Tian Y, Liao X, Xie M, Li W, Chen S. A genome scan for quantitative trait loci associated with Vibrio anguillarum infection resistance in Japanese flounder (Paralichthys olivaceus) by bulked segregant analysis. Marine Biotechnology, 2014, 16(5): 513-521

101. Nie Q, Yue X, Chai X, Wang H, Liu B. Three vibrio-resistance related EST-SSR markers revealed by selective genotyping in the clam Meretrix meretrix. Fish \& Shellfish Immunology, 2013, 35(2): 421-428

102. Chen S L. Fish Sex Control and Cell Engineering Breeding. Beijing: Science Press, 2013 (in Chinese)

103. Hu Q, Zhu Y, Liu Y, Wang N, Chen S. Cloning and characterization of wnt4a gene and evidence for positive selection in half-smooth tongue sole (Cynoglossus semilaevis). Scientific Reports, 2014, 4: 7167

104. Navarro-Martín L, Viñas J, Ribas L, Díaz N, Gutiérrez A, Di Croce L, Piferrer F. DNA methylation of the gonadal aromatase (cyp19a) promoter is involved in temperature-dependent sex ratio shifts in the European sea bass. PLoS Genetics, 2011, 7(12): e1002447

105. Su B, Shang M, Grewe P M, Patil J G, Peatman E, Perera D A, Cheng Q, Li C, Weng C C, Li P, Liu Z, Dunham R A. Suppression and restoration of primordial germ cell marker gene expression in channel catfish, Ictalurus punctatus, using knockdown constructs regulated by copper transport protein gene promoters: potential for reversible transgenic sterilization. Theriogenology, 2015, 84(9): 1499-1512

106. Lillehammer M, Meuwissen T H, Sonesson A K. A low-marker density implementation of genomic selection in aquaculture using within-family genomic breeding values. Genetics, Selection, Evolution, 2013, 45(1): 39 
107. Nirea K G, Sonesson A K, Woolliams J A, Meuwissen T H. Strategies for implementing genomic selection in family-based aquaculture breeding schemes: double haploid sib test populations. Genetics, Selection, Evolution, 2012, 44(1): 30

108. Taylor J F. Implementation and accuracy of genomic selection. Aquaculture, 2014, 420: S8-S14

109. Liu S, Sun L, Li Y, Sun F, Jiang Y, Zhang Y, Zhang J, Feng J, Kaltenboeck L, Kucuktas H, Liu Z. Development of the catfish 250K SNP array for genome-wide association studies. BMC Research Notes, 2014, 7(1): 135

110. Xu J, Zhao Z, Zhang X, Zheng X, Li J, Jiang Y, Kuang Y, Zhang Y, Feng J, Li C, Yu J, Li Q, Zhu Y, Liu Y, Xu P, Sun X. Development and evaluation of the first high-throughput SNP array for common carp (Cyprinus carpio). BMC Genomics, 2014, 15(1): 307

111. Ansai S, Kinoshita M. Targeted mutagenesis using CRISPR/Cas system in medaka. Biology Open, 2014, 3(5): 362-371

112. Chang N, Sun C, Gao L, Zhu D, Xu X, Zhu X, Xiong J W, Xi J J.
Genome editing with RNA-guided Cas9 nuclease in zebrafish embryos. Cell Research, 2013, 23(4): 465-472

113. Edvardsen R B, Leininger S, Kleppe L, Skaftnesmo K O, Wargelius A. Targeted mutagenesis in Atlantic salmon (Salmo salar L.) using the CRISPR/Cas9 system induces complete knockout individuals in the F0 generation. PLoS One, 2014, 9 (9): e108622

114. Li M, Yang H, Zhao J, Fang L, Shi H, Li M, Sun Y, Zhang X, Jiang $\mathrm{D}$, Zhou L, Wang D. Efficient and heritable gene targeting in tilapia by CRISPR/Cas9. Genetics, 2014, 197(2): 591-599

115. Dong L, Xiao S, Wang Q, Wang Z. Comparative analysis of the GBLUP, emBayesB, and GWAS algorithms to predict genetic values in large yellow croaker (Larimichthys crocea). BMC Genomics, 2016, 17(1): 460

116. Dong L, Xiao S, Chen J, Wan L, Wang Z. Genomic selection using extreme phenotypes and pre-selection of SNPs in large yellow croaker (Larimichthys crocea). Marine Biotechnology, 2016, 18 (5): 575-583 